\title{
Dynamic Impact Of Financial Structure On The Volatility Of The Real Exchange Rate
}

Hong-Ghi Min, (Email: hmin@icu.ac.kr), Information and Communications University, Republic of Korea

\begin{abstract}
This study investigates the role of financial structure on the volatility of real effective exchange rates in Korea. (1). Historical developments of size, activity and efficiency of financial structure, including banking and nonblank financial institutions, are investigated for the last three decades in Korea. (2). Using the concept of bank-based and market-based financial structure, it is shown that there exists a stable long-run relationships between the financial structure of an economy and the volatility of real effective exchange rates. (3). Development of market-based system can successfully isolate foreign shocks and reduce the volatility of the real effective exchange rates while increased bank-based system destabilize the volatility of the real exchange. This can be explained by the strong requirement of information disclosure in the stock market induce risk-sharing activities of investors. (4). Policy implication is that transfer of risk from banking sector to stock market or non-bank financial institutions could stabilize the volatility of asset prices.
\end{abstract}

\section{INTRODUCTION}

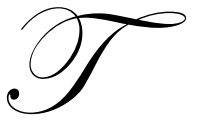

he literature on currency crises has provided a number of suggestions about the possible influence of financial structure on the volatility of asset prices and capital flows. There is by now a documented empirical evidence of the relationship between the financial structure and financial crisis. While this may provide some indirect insight about the relationship between asset volatility - interpreted as extreme variations of prices - and financial structure, a more direct analysis seems to be missing. Although finance theory tells us that the linkage between the financial structure of the economy and the likelihood of financial crises is provided by the volatility of financial and nonfinancial assets this intermediate link is still somewhat unexplored. Real exchange rates often show disrupt corrections in a space of a few quarters, when there seems to be no concrete reason why exchange rates should have changed at all. Sometimes speculative asset price changes dramatically in a matter of days or even hours. On 11 December 1997, the day of the worst crash in Korean foreign exchange market history, the Korean wonU.S. dollar exchange rate almost doubled. Analyses of news service records show that during that interval of time there was virtually no economic news except for the news of the exchange rate drop itself. Such evidence would seem to suggest that the source of market volatility is something loosely called "market psychology," the changing public expectations, attitudes, and theories about the market (Shiller, 1992).

In this paper, we examine how the financial structure of an economy, Korea, affects the volatility of real Korean won-U.S. dollar exchange rates using time-series data. To measure empirically the financial structure of a country we employ the recently developed concept of bank-based versus market-based financial structure (DemirgucKunt and Levine, 1999). In section II, we describe the development of Korea's financial structure. In section III, we investigate the statistical properties of each time series used in this study and test for a stable long-run relationship among financial structure and volatility of the real exchange rate in Korea using Johansen's conintegration technique. In section IV, we investigate the dynamic impact of financial structure on the volatility of real exchange rate using the vector-autoregression model. Conclusions are presented in section V. 


\section{THE DEVELOPMENT OF KOREA'S FINANCIAL STRUCTURE}

This section will investigate the changes in financial structure and the underlying regulation, tax, and legal changes that caused them. The most important policy measure of government-led economic development in Korea was financial policy (e.g., interest rate regulation and policy loans). The heavy intervention of the Korean government in the financial system during the 1960s and 1970s is revealed by its discretionary allocation of funds to target industries through policy loans (credit rationing). This caused misallocation (overinvestment) of financial resources into the heavy manufacturing and chemical industries, which led to creditor bankers' losses. The banking sector suffered from a lack of competitiveness, an accumulation of non-performing assets, and delays in liberalization. Policy loans at preferential interest rates accounted for half of the total credit offered by domestic financial institutions in 1970s and about 30 percent in the 1980s with the expansion of non-bank financial Institutions (NBFIs, hereafter; Bank of Korea, 1995).

In the fifth economic development plan ('82-'86), the Korean government put more emphasis on the stability, efficiency, and social equity within the economy, believing that a massive misallocation of resources in the heavy manufacturing and chemical industries could have been avoided if the functioning of the financial system had been left in the hands of the private sector. The government tried to improve efficiency through the promotion of competition and private initiative. The goals of financial reform were reducing inefficiency and preventing private rent-seeking and foreign control of the financial market (Amsden and Euh, 1993).

\section{Changes In Financial Structure, Size, Activity, And Efficiency In Korea}

Among financial institutions, banks provide funds mostly through loans and they dominated in financial institution borrowings until the 1970s.

Table 1: Financial Market Composition Of Korea*

\begin{tabular}{|c|c|c|c|c|c|}
\hline & $\mathbf{1 9 7 0 - 7 4}$ & $\mathbf{1 9 7 5 - 7 9}$ & $\mathbf{1 9 8 0 - 8 4}$ & $\mathbf{1 9 8 5 - 8 9}$ & $\mathbf{1 9 9 0 - 9 4}$ \\
\hline Financial Institutions & 38.0 & 40.7 & 45.6 & 48.7 & 52.5 \\
\hline Banks & 29.2 & 26.2 & 23.2 & 20.3 & 19.2 \\
\hline Non-Banks & 8.8 & 14.5 & 22.4 & 28.4 & 33.2 \\
\hline Security Market & 11.1 & 15.6 & 20.0 & 27.1 & 27.0 \\
\hline Stocks & 9.7 & 11.1 & 11.9 & 16.4 & 11.4 \\
\hline Bonds & 1.3 & 4.5 & 8.1 & 10.7 & 15.6 \\
\hline CP Market & 0.5 & 1.4 & 3.2 & 4.7 & 4.0 \\
\hline Foreign Market & 13.6 & 13.3 & 6.0 & 0.2 & 2.2 \\
\hline Other Finance & 36.9 & 29.0 & 25.2 & 19.3 & 14.4 \\
\hline Total & 100 & 100 & 100 & 100 & 100 \\
\hline
\end{tabular}

Notes: * denotes the non-financial sector's fund raising, CP denotes commercial paper, Source: The Financial System in Korea (1995), Bank of Korea.

Their relative importance has gradually declined, slipping from 29.2 percent of the market in the first half of the 1970s to 19.2 percent in the first half of the 1990s. Whereas Table 1 shows that the market shares of non-banks and securities market increased over the period 1970-74 to 1990-94 from 8.8 percent to 33.2 percent and from 11.1 percent to 27.0 percent respectively. The share of deposits held by non-banks increased from 31.6 percent in 1980 to 67.6 percent in 1995

Despite the slow pace of reform, Korea's financial market experienced growth in overall size and activity. Korean financial depth increased from 49.4 percent in 1981 to 103.2 percent in 1989 and to 150.0 percent in 1995, mostly due to the growth in the non-banking sector. However, stock market capitalization to GDP grew even more over this period, from 6 percent to 63.4 percent. This explains the growth in the stock market's relative size, which started out at 20 percent in early 1980s, but ended the decade at 90 percent. During the same period, stock market liquidity and bank credit to the private sector also increased, leading to an increase in overall activity from 44 percent 
to 82 percent of GDP. However, the growth in stock market liquidity far outweighed that in bank credit as can be seen from relative activity figures. Looking at efficiency indicators, relative efficiency increased whereas overall efficiency fell during the period. This is because although stock market turnover increased with liberalization, banking spreads increased even more.

Table 2: Market Share of Financial Institutions in Korea

\begin{tabular}{|c|c|c|c|c|c|c|c|c|}
\hline & \multicolumn{4}{|c|}{ Loans (in percent) } & \multicolumn{4}{|c|}{ Deposits (in percent) } \\
\hline & 1980 & 1985 & 1990 & 1995* & 1980 & 1985 & 1990 & 1995* \\
\hline \multirow[t]{2}{*}{ Deposit Money Bank** } & 63.3 & 58.4 & 48.3 & 42.9 & 68.4 & 53.5 & 41.0 & 32.4 \\
\hline & \multicolumn{4}{|c|}{$-32.2 \%$} & \multicolumn{4}{|c|}{$-52.6 \%$} \\
\hline \multirow[t]{2}{*}{ NBFI's *** } & 36.7 & 41.6 & 51.7 & 57.1 & 31.6 & 46.5 & 59.0 & 67.6 \\
\hline & \multicolumn{4}{|c|}{$55.6 \%$} & \multicolumn{4}{|c|}{$113.9 \%$} \\
\hline \multirow[t]{2}{*}{ A.Development Bank } & 14.8 & 10.8 & 8.3 & 8.0 & 3.8 & 4.1 & 3.1 & 4.2 \\
\hline & \multicolumn{4}{|c|}{$-45.9 \%$} & \multicolumn{4}{|c|}{$10.5 \%$} \\
\hline \multirow[t]{2}{*}{ B.Savings Institutions } & 13.0 & 16.3 & 25.3 & 33.3 & 13.5 & 15.5 & 27.1 & 36.5 \\
\hline & \multicolumn{4}{|c|}{$152.6 \%$} & \multicolumn{4}{|c|}{$170 \%$} \\
\hline \multirow[t]{2}{*}{ C.Investment Institute } & 5.8 & 7.6 & 8.1 & 6.8 & 9.5 & 15.8 & 16.2 & 15.5 \\
\hline & \multicolumn{4}{|c|}{$17.2 \%$} & \multicolumn{4}{|c|}{$63 \%$} \\
\hline \multirow[t]{2}{*}{ D.LifeInsurance Co. } & 3.1 & 6.9 & 10.0 & 9.0 & 4.8 & 11.1 & 12.6 & 11.4 \\
\hline & \multicolumn{4}{|c|}{$190.3 \%$} & \multicolumn{4}{|c|}{$137.5 \%$} \\
\hline
\end{tabular}

Notes: * denotes the amount by the end of June, 1995. ** denotes money deposits at banks. *** denotes Non-banking Financial Institutions. \% denotes the total growth rate between June 1980 and June 1995. Source: The Financial System in Korea (1995), Bank of Korea.

\section{Development Of Non-Bank Financial Institutions}

In this section, we analyze the development of non-bank financial institutions (NBFIs), their special treatment by law and regulation, their structure and business activities, their role in stimulating and mobilizing savings, and their contribution to Korea's economic development Many NBFIs were introduced in 1972 in response to the Presidential Emergency Decree for Economic Stabilization and Growth. Their numbers and volume of funds grew significantly during the rapid economic growth of the 1970s and 1980s. A further contribution to their rapid growth came from the relatively higher interest rates permitted to them and the greater degree of autonomy in management they were allowed compared to traditional banks. In 1982, requirements for establishing NBFIs were reduced and consequently twelve short-term finance companies and 57 mutual savings and finance companies began operations. During the period 1987 to 1990, five securities trust companies and eighteen life insurance companies were in operation (Bank of Korea,1995).

NBFIs can be classified into four categories according to their business activities: i) development institutions, which consist of the Korea Development Bank, the Export-Import Bank of Korea, and the Korea Long Term Credit Bank; ii) investment institutions, which consist of investment and finance companies, merchant banking corporations, and securities investment trust companies; iii) savings institutions including trust accounts of banks, mutual savings and finance companies, credit unions, mutual credit facilities, community credit cooperatives, and postal savings; and iv) life insurance institutions.

Out of these four categories of NBFIs, investment, and life insurance institutions grew most rapidly during the period 1980-1995. These NBFIs have contributed significantly to the stimulation and mobilization of savings since they were able to circumvent the interest-rate ceilings on both the sources and uses of funds (Koo, 1993). Table 2 shows that over the period 1980-1995, the share of loans made by NBFIs increased from 36.7 percent to 57.1 percent. On the demand side, high real interest rates (due to slowing price increases in the early 1980s) jeopardized the viability of firms with high financial leverage. Because of the repressed commercial bank interest rates, corporations not supported by the government were forced to borrow from NBFIs. NBFIs evaded the low interest-rate policy of MOF by requiring compensating balances that borrowers had to redeposit in the same financial institution, thereby raising the effective interest rates on the original loans (Bank of Korea, 1995). 


\section{A Measure Of Financial Structure}

The measurement of financial structure in this study draws heavily on the recent work by Demirguc-Kunt and Levine (1999) that derived several findings on the relationship between financial structure and per capita income level. According to their study, in higher income countries, banks and other financial intermediaries as well as stock markets and the overall financial system tend to be larger, more active, and more efficient. In higher income countries insurance companies, pension funds, and other nonblank financial intermediaries are larger as a share of GDP.

For practical purposes, we used three variables as indicators of Korea's financial structure: bank assets to GDP (claims on the private sector by commercial banks to GDP, BANK); non-banking financial institution's assets to GDP as a measurement of other financial institution's size (NBFI); and stock-market capitalization to GDP as a measure of stock market development (MK). Variable definitions are given in the Appendix. Figure 1 shows the changing pattern of the financial structure in Korea and Table 2 shows the volatility of four financial variables.

\section{THE DATA AND THEIR STATISTICAL PROPERTIES}

In this section we define the variables used in this study and test the stationarity of those variables using two different unit root test procedures.

\section{The Data And Their Statistical Properties}

All quarterly data are from the March 1999 issue of the IMF's International Financial Statistics, CD-Rom version, and are seasonally adjusted using exponential smoothing. Data definitions are found in the Appendix. A control variable is used to isolate the effects of structural variables (that are expected to maintain their impact over the long run) from the short-run effects of policy -- monetary or fiscal -- on the volatility of the real exchange rates a la Krumm (1993). Volatility responds to both real and monetary variables. Monetary and fiscal variables are combined into one macroeconomic control variable, $\mathrm{VV}$, which is defined as the percentage change in domestic credit over and above the percentage change in GDP, foreign prices, and the nominal exchange rate.

$\mathrm{VV}=\mathrm{DC}^{*}-\mathrm{Y}^{*}-\mathrm{Pf}^{*}-\mathrm{NE}^{*}$

where DC is domestic credit, Y is GDP, Pf is U.S. WPI, NE is the nominal exchange rate to the U.S. dollar, and * indicates percentage change. In order to examine the stationarity of each time series, we conducted unit root tests. Table 3 reports the results from the Augmented Dickey-Fuller and Paco Goerlich Tests, which reveal that all series have unit roots.

Table 3: Tests Of Unit Roots

Augmented Dickey-Fuller Test

\begin{tabular}{|c|c|c|c|c|}
\hline Variable & Lags & ADF & ADF $_{\square}$ & $\begin{array}{c}\text { Joint Test Of Unit } \\
\text { Root And No }\end{array}$ \\
\hline VRX & $2(1)$ & -2.29 & -10.7 & 4.0 \\
\hline NBVB & $0(0)$ & 1.15 & 0.82 & 3.27 \\
\hline BANK & $14(1)$ & -0.63 & -0.87 & 2.29 \\
\hline MK & $8(8)$ & -1.25 & -3.07 & 1.23 \\
\hline
\end{tabular}

Note: $* *$ denotes that the estimate is significant at 5 percent critical level.

Paco Goerlich Test

\begin{tabular}{|c|c|c|c|c|c|}
\hline Variable & $\begin{array}{c}\text { AR } \\
\text { Corrections }\end{array}$ & Constant, Trend & Constant & $\begin{array}{c}\text { No constant, } \\
\text { No Trend }\end{array}$ & Conclusion \\
\hline VRX & 4 & -1.29 & -1.07 & -1.12 & Unit root, no drift \\
\hline NBVB & 4 & -2.66 & -0.12 & N.A. & Unit root, drift \\
\hline BANK & 4 & -1.79 & -1.03 & 1.61 & Unit root, no drift \\
\hline MK & 4 & -1.98 & 2.19 & 1.29 & Unit root no drift \\
\hline
\end{tabular}

Note: $* *$ denotes that the estimate is significant at 5 percent critical level. 
Figure 1: Cumulative Impulse Response Functions Of REER Volatility

Shocks To Bank Financial Institutions' Assets

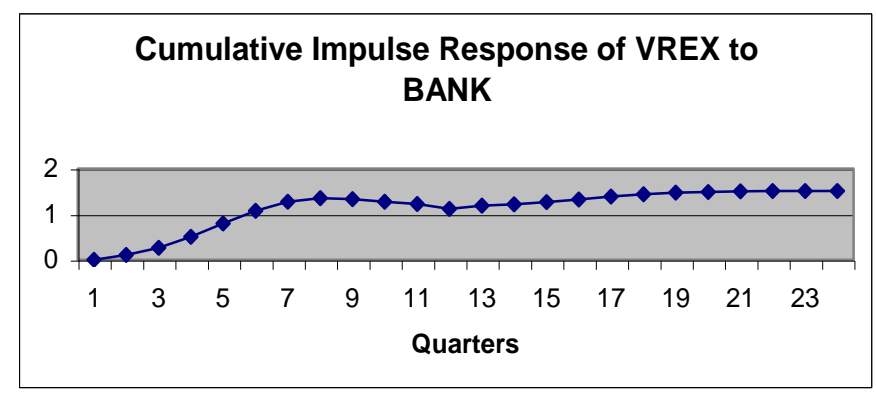

Shocks To Stock Market Capitalizations

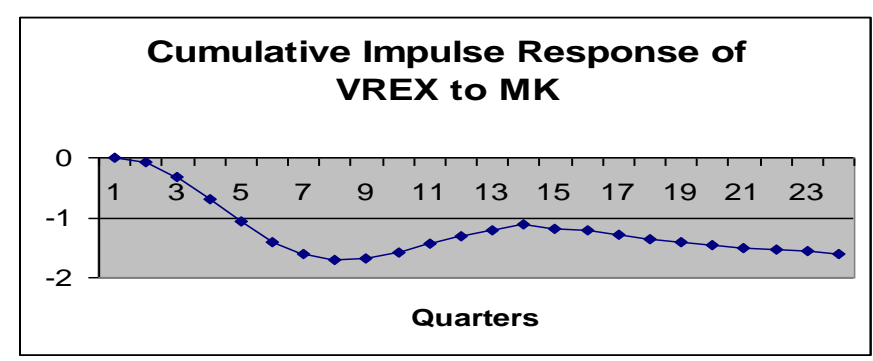

Shocks To Non-bank Financial Institutions

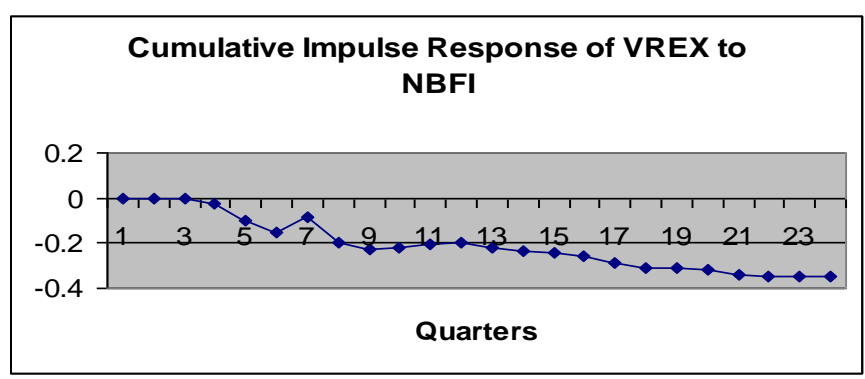

\section{Johansen's Cointegration Test}

Since all variables are non-stationary, we use Johansen's co-integration analysis to test whether those variables have co-integrating vectors. Johansen (1988) and Johansen and Juselius (1990) developed a cointegration test methodology that overcome most of the problems of the previous two-step approach.

Johansen and Juselius (1990) considered the following general model:

$$
X_{t}=\Pi_{1} X_{t-1}+\ldots . .+\Pi_{t-k} X_{t-k}+v+\varepsilon_{t}, t=1, \ldots . T
$$

where $X_{t}$ is a vector of variables $; \varepsilon_{1}, \ldots . ., \varepsilon_{t}$ are independent and normal errors with zero mean and covariance matrix $\sum \square \mathrm{X} \mathrm{t-k,X} 0$ are fixed; and $\mathrm{v}$ is an intercept vector. Economic time series are often non-stationary and systems such as the above vector-autoregressive representation (VAR) can be written in the conventional first- 
difference form:

$$
X_{t}=\Pi_{1} X_{t-1}+\ldots . .+\Pi_{t-k} X_{t-k}+v+\varepsilon_{t}, t=1, \ldots . T
$$

where $\Gamma_{i}=-\left(1-\Pi_{1}-\Pi_{2}-\ldots \ldots \ldots . . .-\Pi_{k}\right), i=1,2, \ldots, k-1$ and $\Pi=-\left(1-\Pi_{1}-\Pi_{2}-\ldots \ldots \ldots . .-\Pi_{k}\right)$.

The only level term in equation (3) is $\Pi X_{t-k}$. Thus, only the $\Pi \square$ matrix contains information about the long-run relationship between the variables in the data vector. There are three possible cases:

- If the $\Pi$ matrix has rank zero then all variables in $\mathrm{X}$ are integrated of order one or higher and the VAR has no long-run properties;

- $\quad$ If the $\Pi \square$ matrix has rank p (i.e., it is of full rank ), the variables in $\mathrm{X}$ are stationary; and

- $\quad$ If $\Pi$ matrix has rank r ( $0<\mathrm{r}<\mathrm{p}$ ), $\Pi \square$ can be decomposed into two distinct (p*r) matrices $\alpha \square$ and $\beta \square$ such that $\Pi=\alpha \beta^{\prime}$.

The third case implies that there are $\mathrm{r}$ cointegrating vectors. The parameters of the cointegrating vectors are contained in the $\beta \square$ matrix. Therefore $\square \beta^{\prime} \mathrm{X}$ is stationary even though Xt itself is nonstationary. The $\alpha$ matrix gives weights with which the cointegrating vectors enter each equation of the system. To determine the number of cointegrating vectors, r, Johansen and Juselius (1990) used two likelihood-ratio tests. The first test is based on the maximal eigenvalue ( $\lambda$ MAX) -- the null hypothesis is that there are at most $r$ cointegrating vectors against the alternative $r+1$ cointegrating vectors. The second test is based on the trace of the stochastic matrix (TRACE) -- the null hypothesis is that there are at most $r$ cointegrating vectors against the alternative hypothesis that there are $r$ or more cointegrating vectors. Two likelihood-ratio tests for the existence and cointegrating vectors are reported in Table 4. Johansen's cointegration tests are implemented using four lags and for four sets of five variables which include the volatility, financial structure, and control variables.

Table 4 shows that the volatility of the real effective exchange rate has three cointegrating vectors with the financial structure variables at the 10 percent critical level based on both $\lambda$ max and Trace statistics. One of the cointegrating vectors can be written as follows:

.024 VREX + 2.052 NBFI - 13.05 BANK -.723 MK + 0.151 VV = 0 (7).

This cointegrating vector is consistent with the impulse response analysis of the vectorautoregression model presented in Figures 4-A and 4-B.

Table 4: Johansen's Cointegration Test (Endogenous Series: VREX, NBFI, BANK, MK, VV)

Lags In The Model: 4, No. Of Observations=65, No. Of Observations - No. Of Variables $=45$

\begin{tabular}{|c|c|c|c|c|c|c|}
\hline Eigen-Value & L-max & Trace & H0: $\mathbf{r}$ & p-r & L-max90 & Trace90 \\
\hline 0.8804 & $138.03 * *$ & $212.02^{* *}$ & 0 & 5 & 18.96 & 55.54 \\
\hline 0.4726 & $41.59^{* *}$ & $73.99^{* *}$ & 1 & 4 & 15.00 & 36.58 \\
\hline 0.3126 & $24.37 * *$ & $32.40^{* *}$ & 2 & 3 & 11.23 & 21.58 \\
\hline 0.1049 & 7.20 & 8.03 & 3 & 2 & 7.37 & 10.35 \\
\hline 0.0127 & 0.83 & 0.83 & 4 & 1 & 2.98 & 2.98 \\
\hline
\end{tabular}

Notes: ** denotes significant at 10 percent.

Cointegrating Vector

\begin{tabular}{|c|c|c|c|c|}
\hline VREX & NBFI & BANK & MK & VV \\
\hline 0.024 & 2.052 & -13.05 & -0.723 & 0.151 \\
\hline 0.496 & 5.429 & -27.166 & -1.250 & -0.594 \\
\hline
\end{tabular}




\section{DYNAMIC ANALYSIS USING A VECTOR-AUTOREGRESSION MODEL}

In this section we use the vector-autoregression model to examine the dynamic impact of financial structure on the volatility of the financial variables.

\section{A Vector-Autoregression Model}

We will test the dynamic impact of changing financial structure on the volatility of 솓 real exchange rates using the vector-autoregressive model presented in equations (5).

$$
X_{t}=\sum_{s=1}^{L} \Phi(L) X_{t-s}+\varepsilon_{t}, \quad E\left(\varepsilon_{t} \varepsilon_{t}^{\prime}\right)=\Sigma
$$

Let the vector of stationary variables be $\mathrm{X}=\{v r x, s m k, b a n k, n b f i, p s\}$, the vector of shocks be $\varepsilon_{t}=\left\{\varepsilon^{v r x}, \varepsilon^{s m k}, \varepsilon^{b a n k}, \varepsilon^{n b f i}, \varepsilon^{p s}\right\}$, and $\Gamma$ and $\Phi$ are vectors of coefficients for the vector-autoregressive model and $\mathrm{L}$ is the lag operator. Where $\boldsymbol{v r x}$ is the volatility of the real effective exchange rate, smk is the amount of stock market capitalization divided by GDP, $\boldsymbol{b a n k}$ is claims on the private sector by commercial banks, $\boldsymbol{n} \boldsymbol{b} \boldsymbol{f} \boldsymbol{i}$ is the ratio of bank to non-bank financial institutions' assets, and $\boldsymbol{p s}$ is the macroeconomic policy stance variable to control for the impact of macroeconomic policies.

\section{Impulse Response Function Analysis}

The goal of this section is to investigate the dynamic impact of financial structural variables on the volatility of the real exchange rates. Granger-causality amongst these variables is examined and the results are reported in Table 5.

Table 5: Granger-Causality Test Volatility Of Real Effective Exchange Rate

\begin{tabular}{|c|c|c|c|c|c|}
\hline & VREX & NBFI & BANK & MK & VV \\
\hline VREX & $.000^{* *}$ & .14 & .29 & .25 & .90 \\
\hline NBFI & .65 & $.000^{* *}$ & $.001^{* *}$ & $.006^{* *}$ & $.035^{* *}$ \\
\hline BANK & $.018^{* *}$ & $.000^{* *}$ & $.000^{* *}$ & $.000^{* *}$ & $.014^{* *}$ \\
\hline MK & .23 & $.000^{* *}$ & .75 & $.000^{* *}$ & .35 \\
\hline VV & .69 & .23 & $.019^{* *}$ & .63 & $.023^{* *}$ \\
\hline
\end{tabular}

Notes: Figures are significance probabilities. ** denotes significant at 5 percent.

Based on these causality tests and economic theory, the ordering of the variables in the vector-autoregression is determined. Various different orderings are tried to see the robustness of the test result. The dynamic impact of financial structure and macroeconomic policy stance variables are analyzed through the computation of variance decompositions (VDCs) and impulse response functions (IRFs) which, in turn, are based on the moving-average representation of the VAR model and reflect both direct and indirect effects. In particular, the VDCs for vrex indicate the percentage of the forecast-error variance in the vrex accounted by the financial structure and VV.

\section{Dynamic Impact Of Financial Structure On The Real Exchange Rates}

An optimal lag of four is chosen based on the likelihood-ratio test and the model is then estimated. Since different orderings of the variables in the VAR estimation yield different results, various orderings based on the Granger-causality tests reported in Table 4 were tried. However, different orderings did not bring about significant differences. From the impulse response function and variance decomposition of forecast-error variances, we find the following: 


\section{Volatility Of Real Effective Exchange Rate}

- $\quad$ SMK - The impulse response functions are shown in Table 1. Panel A in Table 1 shows that stock market capitalization (smk) decreases the volatility of the real effective exchange rate. Increased stock market capitalization leads to the increased information dissemination in the market and increased information in the market, in turn, provides investors incentives of risk sharing (Lakonishok et al, 2002; Albuquerque, 2003). This risk sharing behavior of investors decrease the volatility of the real exchange rates. Patten (2000) reports evidence that increased information disclosure in the stock market decreases volatility of trading volume while Gintschel and Markov (2004) reports that regulation fair dsclosure stabilized stock prices.

- $\quad$ BANK - The increased private claims of commercial banks to GDP (BANK) increase the volatility of the real exchange rates in Korea. Poorer information generation of increased banking activities could lead to the herding of investors in the foreign exchange market (Welch, 2000: Dahlquist et al, 2004).

- $\quad$ NBFI - Increased activities of non-bank financial institutions reduce the volatility of the real exchange rates. This effect can be explained by the transfer of risk from banking sector to other financial institutions.

\section{Variance Decomposition}

Variance decomposition of the VAR model is reported in Table 6.

Table 6: Variance Decomposition Of The VAR Model Decomposition Of Volatility Of Real Effective Exchange Rate

\begin{tabular}{|c|c|c|c|c|c|}
\hline & \multicolumn{5}{|c|}{ Percentage of the forecast-error variance of VREX explained by: } \\
\hline Quarters & VREX & NBFI & BANK & MK & VV \\
\hline 4 & 90.05 & 0.08 & 2.73 & 6.21 & 0.92 \\
\hline 8 & 80.23 & 0.29 & 6.80 & 11.57 & 1.08 \\
\hline 12 & 79.81 & 0.30 & 6.56 & 11.91 & 1.40 \\
\hline 16 & 79.61 & 0.32 & 6.60 & 11.98 & 1.48 \\
\hline 20 & 79.24 & 0.35 & 6.72 & 12.19 & 1.48 \\
\hline 24 & 79.16 & 0.36 & 6.71 & 12.27 & 1.48 \\
\hline
\end{tabular}

With the exception of the real effective exchange rate itself, stock market capitalization to GDP plays the most important role in explaining the forecast error variance of the volatility of the real effective exchange rate, explaining about 12 percent of the forecast error variance by 8 quarters. The next most important explanatory variable is private claims of the banking sector (BANK), explaining about 7 percent by 8 quarters. However, the policy stance and non-bank financial institutions (NBFI) variables explain very little of the forecast-error variance of the volatility of the real effective exchange rate. Table 6 shows the variance decomposition of the volatility of the real effective exchange rate in Korea.

\section{CONCLUSIONS}

This study identifies the role of financial structure on the volatility of the real effective exchange rates. We used the concept of market-based and bank-based financial structure developed by Demirguc-Kunt and Levine (1999) to investigate the changing role of financial structure on the volatility of the real exchange rates. From this case study of Korea, we have two unique findings. First, it is shown that there exists a long-run stable relationship between financial structure of an economy and the volatility of real effective exchange rates. Second, we find that the dynamic impact of financial structure on the volatility of the real effective exchange rates is asymmetric, i.e., increased stock market capitalization decrease the volatility of the real effective exchange rates whereas increased private claims of commercial banks to GDP increase the volatility of the real effective exchange rates. This implies that as Korea's financial structure moves from a bank-based to a market-based system, the volatility of the real effective exchange rate decrease and this is true even in the mid-1980s with a more flexible exchange rate. In other words, development of market-based system can successfully isolate foreign shocks and reduce the volatility of the real effective exchange rates while development of bank-based system increases the volatility of the real exchange. This can be explained by 
the strong requirement of information disclosure in the stock market induce risk-sharing activities of investors and stabilize the asset price. Policy implication is that transfer of risk from banking sector to stock market or non-bank financial institutions could stabilize the volatility of asset prices. Future study will investigate whether the findings of this study are robust with respect to the cross-country data.

\section{ACKNOWLEDGEMENT}

This study is supported by the Korea Research Foundation Grant-2003-041-B0012. The authors are grateful to to Giovanni Majnoni, Judith McDonald, S. Kwack and other seminar participants at the World Bank for their helpful comments but all remaining errors are our own.

\section{REFERENCES}

1. Ahmed, B., Ickes, P. Wang, and B. S. Yoo, 1993. International Business Cycle, American Economic Review, 83, 335-59.

2. Amsden, A. H. and Y. D. Euh, 1993. South Korea's 1980s Financial Reforms: Good Bye Financial Repression (Maybe), Hello New Institutional Restraints, World Development, 21, 379-390.

3. Bank of Korea, 1990, 1995. The Financial System in Korea, Seoul, Korea.

4. Cho, Y. J. and J. K. Kim, 1995. Credit Policies and the Industrialization of Korea, World Bank Discussion Paper No. 286, The World Bank, Washington D.C.

5. Demirguc-Kunt, A. and R. Levine, 1999. Bank-based and Market-based Financial Systems: Cross-Country Comparisons, mimeo, The World Bank.

6. Demirguc-Kunt, A. and V. Maksimovic, 1996a. Financial Markets and Firm Debt Maturity, World Bank Working Paper No. 1686, The World Bank.

7. , 1996b. Financial Constraints, Uses of Funds and Firm Growth: An International Comparison, World Bank Working Paper No. 1671, The World Bank.

8. Johansen, Soren, 1988, Statistical Analysis of Cointegrating Vectors, Journal of Dynamics and Control, 231254.

9. Johansen, S. and K. Juselius, 1990, Maximum Likelihood Estimation and Inference on Cointegration -- With Application to the Demand for Money, Oxford Bulletin of Economics and Statistics, May, 169-210.

10. Jung, J. and J. W. Lee, 1993, Recent Financial Reforms in Korea: Real Name Financial System Launched, Korean Financial Review, vol. 3, no. 3, 3-22.

11. Kang, M. S., 1990, Money Market and Monetary Policy in Korea, Korea Development Institute, Seoul, Korea.

12. Koo, B. H., 1993, Industrial Policy and Financial Reforms in Korea, in Financial Sector Reforms in Asia and Latin American Countries, edited by Shakil Faruqi, The World Bank.

13. Krumm, K. L., 1993, A Medium-term Framework for Analyzing the Real Exchange Rate with Applications to the Philippines and Tanzania, World Bank Economic Review, 2, 219-245.

14. Park, J. H., 1993, Financial liberalization and Internationalization in Korea, Korean Financial Review, 3, 323.

\section{DATA APPENDIX: SOURCES AND DEFINITIONS}

1. RX: real effective exchange rate defined as a six-month window standard deviation for each quarter; data are from JP Morgan.

2. BOND: government bond yield on housing (IFS line 61).

3. STK: stock price index (IFS line 62).

4. $\quad$ MMR: money-market rate (IFS line 60b).

5. VRX: volatility of real effective exchange rate defined as a six-month window standard deviation for each quarter; data are from JP Morgan.

6. VBOND: volatility of the government bond yield on housing defined as a six-month window standard deviation for each quarter (IFS line 61).

7. VSTK: volatility of the stock price defined as a six-month window standard deviation for each quarter (IFS 
line 62).

8. VMMR: volatility of the money-market rate defined as a six-month window standard deviation for each quarter (IFS line 60b).

9. NBFI: Other financial institutions' domestic assets (IFS lines 42a-d) to GDP (IFS line $90 \mathrm{bp}$ ).

10. BANK: Commercial banks' domestic assets (IFS lines 22 a-d) to GDP (IFS line 90 bp).

11. MK: Stock market capitalization (Monthly Bulletin of the Stock Market) to GDP (IFS line $90 \mathrm{bp}$ ).

12. VV: Macroeconomic Control Variable defined in the text.

NOTES 